\title{
POTONGAN KOMERSIAL KARKAS AYAM BROILER STRAIN COBB YANG MENGALAMI PEMBATASAN PAKAN DAN PEMBERIAN SUMBER SERAT KASAR BERBEDA PADA PERIODE GROWER
}

\author{
Megawati Tumiran, John E. G. Rompis*, Jet S. Mandey, Fredy J. Nangoy, dan \\ Jola J. M. R. Londok \\ Fakultas Peternakan, Universitas Sam Ratulangi Manado, 95115
}

\begin{abstract}
ABSTRAK
Penelitian dilakukan untuk mengetahui pengaruh pembatasan pakan dan pemberian sumber serat kasar berbeda terhadap potongan komersial karkas ayam broiler. Penelitian menggunakan 24 ekor ayam broiler Strain Cobb. Pembatasan pakan $20 \%$ dan sumber serat yang berbeda diberikan pada ayam berumur 21 hari sampai 28 hari kemudian pemberian pakan komersial ad libitum sampai panen (42 hari). Rancangan yang digunakan adalah Rancangan Acak Lengkap (RAL) dengan pola Faktorial $2 \times 4$ dan 3 ulangan. Perlakuan terdiri atas: faktor A (pembatasan pakan) dengan A0 (tanpa pembatasan) dan A1 (pembatasan 20\%). Faktor B (sumber serat) dengan B0 (pakan komersial), B1 (pakan komersial dengan kulit kopi), B2 (pakan komersial dengan dedak padi), dan B3 (pakan komersial dengan ampas kelapa). Terdapat 8 kombinasi perlakuan yaitu: A0B0, A0B1, A0B2, A0B3, A1B1, A1B2 dan A1B3. Peubah yang diukur yaitu: persentase dada, persentase paha atas, persentase paha bawah, persentase sayap, dan persentase punggung. Analisis data menggunakan ANOVA dan uji lanjut BNJ. Hasil analisis menunjukkan bahwa interaksi berbeda sangat nyata $(\mathrm{P}<0,01)$ terhadap persentase paha atas, berbeda nyata $(\mathrm{P}<0,05)$ terhadap bobot karkas. Perlakuan sumber serat berbeda nyata $(\mathrm{P}<0,05)$ terhadap persentase
\end{abstract}

\footnotetext{
*Korespondensi (corresponding author):

E-mail: jegronne@yahoo.co.id
}

paha bawah, berbeda sangat nyata $(\mathrm{P}<0,01)$ terhadap bobot hidup, persentase dada dan persentase punggung. Perlakuan pembatasan pakan berbeda nyata $(\mathrm{P}<0,05)$ terhadap persentase sayap. Pembatasan pakan $20 \%$ dengan ampas kelapa sebagai sumber serat pakan memberikan potongan komersial karkas ayam broiler strain Cobb terbaik.

Kata Kunci: Potongan komersial, Pembatasan pakan, Serat kasar.

\section{ABSTRACT}

Study was conducted to evaluate the effect of feed restriction and source of different crude fiber on carcass weight and commercial pieces of broiler with Cobb strain. Study was using 24 broilers with Cobb Strain. Restriction of 20 percent feed and different sources of crude fiber were applied to broilers at age of 21to 28 days old. Ration was fed ad libitum to broilers until birds reached age of 42 days old. . This research was using a Completely Randomized Design (CRD) in Factorial pattern of $2 \times 4$ with 3 replications. As a factor $A$ was restricted feeding consisted of without restrictions (A0), and 20 percents restricted ration (A1). A factor $\mathrm{B}$ was source of crude fiber consisted of commercial feed (B0), commercial feed with coffee hull meal (B1), commercial feed with rice bran (B2), and commercial feed with coconut pulp (B3). There were treatment combinations including $\mathrm{A} 0 \mathrm{~B} 0$, A0B1, A0B2, A0B3, A1B0, A1B1, A1B2 and A1B3. The variables measured were 
percentages of commercial pieces consist of breast, thigh, wing and brisket. The data analyzed used variance analysis. The honestly significance difference test was used to determine which one of treatment was significantly different from each other. The results showed that the combination treatment of feed restriction and source of crude fiber in feed gave a very significant different effect $(\mathrm{P}<0.05)$ on carcass weight of broiler with Cobb strain. Sources of fiber crude affected significantly $(\mathrm{P}<0.05)$ percentages of thigh, breast, brisket and live weight. Treatment of feed restriction affected significantly $(\mathrm{P}<0.05)$ percentage of wing. Restriction of 20 percents with coconut pulp as source of crude fiber produced better commercial carcass of broilers withCobb strain.

Keywords: Feed restriction, crude fiber source, broiler commercial pieces, Cobb strain

\section{PENDAHULUAN}

Ayam broiler merupakan salah satu penyumbang terbesar protein hewani di Indonesia dan merupakan komoditas unggulan. Industri daging ayam broiler berkembang pesat karena kebutuhan konsumen akan daging ayam sangat besar. Keberhasilan dalam pemeliharaan broiler salah satunya ditentukan oleh pakan, karena pakan dapat mempengaruhi jumlah dan kualitas karkas sehingga pemilihan bahan pakan yang tepat sangat diperlukan.

Program pembatasan pakan (restricted feeding) merupakan salah satu cara yang digunakan untuk memberikan pakan pada ternak sesuai dengan kebutuhan hidup pokoknya pada umur dan periode tertentu (Kusuma et al., 2016). Selain itu dapat menurunkan konversi pakan dan menurunkan lemak tubuh. Beberapa peneliti seperti Londok et al. (2012) dan Tulung et al. (2015) telah melakukan penelitian mengenai efektivitas pembatasan pakan pada ternak ayam sampai $20 \%$ memberikan konversi pakan terbaik dan level serat kasar (sampai 10\%) serta lama pemberian (sampai 16 hari), toleransi ayam pedaging terhadap lamanya pemberian pakan hanya sampai 8 hari dengan kadar serat kasar sampai 10\% dalam pakan. Pemberian pakan sumber serat seperti kulit kopi, dedak padi dan ampas kelapa pada ayam broiler digunakan juga dalam penelitian ini karena merupakan sumber pakan lokal yang sering dijumpai oleh peternak selain mudah didapatkan, dan harganya lebih terjangkau.

Karkas merupakan bagian tubuh yang sangat menentukan dalam produksi ayam daging. Kualitas karkas yang baik merupakan hal utama yang harus diperhatikan oleh peternak ayam broiler, karena semakin selektifnya konsumen dalam memilih produk peternakan khususnya daging. Merkley et al. (1980) menyatakan bahwa potongan komersial karkas dibagi menjadi beberapa bagian, yaitu dada (breast), paha atas (thigh muscle), paha bawah (drumstick) dan sayap 
(wing) dan punggung (brisket). Potongan komersial karkas ayam broiler biasanya berdasarkan kebutuhan dan permintaan konsumen. Tulung (1999) mengatakan bahwa produksi daging yang dihasilkan oleh jenis ternak dipengaruhi oleh kecepatan tumbuh yang berbeda dan berdampak pada nilai ekonomis dari masing-masing jenis ternak Lanjut dikatakan bahwa kualitas karkas dipengaruhi oleh proporsi organ. Mahmood et al. (2007) menyatakan bahwa pembatasan pakan tidak mempunyai dampak yang buruk terhadap karakteristik karkas yang dihasilkan. Pembatasan pakan diharapkan dapat meningkatkan produksi karkas.

Berdasarkan uraian di atas maka telah dilaksanakan penelitian dengan tujuan untuk mendapatkan potongan komersial karkas ayam broiler strain Cobb yang mengalami pembatasan pakan dan pemberian sumber serat berbeda pada periode grower.

\section{MATERI DAN METODE PENELITIAN}

\section{Waktu dan Tempat}

Penelitian ini dilaksanakan selama 6 minggu di kandang percobaan Fakultas Peternakan Universitas Sam Ratulangi Manado, mulai dari 23 Mei sampai 04 Juli 2018.

\section{Materi Penelitian}

Penelitian ini menggunakan 24 ekor ayam strain Cobb yang berumur 42 hari dengan bobot badan \pm 2080 gram dari PT. Charoen Pokphand Indonesia. Kandang yang digunakan adalah kandang baterai yang berukuran per unit $33 \times 40 \times 60 \mathrm{~cm}^{3}$ sebanyak 24 unit dan berisi 2 ekor ayam. Peralatan yang digunakan adalah timbangan, kipas angin, sapu, kantong pelastik, plester, ember, alat tulis menulis, dan lampu.

\section{Pakan Percobaan}

Pakan yang digunakan adalah pakan komersial dan pakan sumber serat yang terdiri dari kulit kopi, dedak padi, ampas kelapa dan tepung ikan. Penyusunan pakan sesuai perlakuan dapat dilihat pada Tabel 2. Formulasi ransum mengacu pada kebutuhan ayam broiler berdasarkan dari PT. Charoen Pokphand. Pakan komersial yang digunakan $\mathrm{CP}$ 12. Pakan perlakuan diberikan pada fase grower. Pembatasan pakan $20 \%$ dan sumber serat yang berbeda diberikan pada ayam berumur 21 hari sampai 28 hari kemudian pemberian pakan komersial ad libitum sampai panen (42 hari). 
Tabel 1. Komposisi bahan penyusun pakan perlakuan

\begin{tabular}{lccccccc}
\hline \multirow{2}{*}{ Bahan Pakan } & BK & PK & LK & SK & Ca & P & EM \\
\cline { 2 - 8 } & $(\%)$ & $(\%)$ & $(\%)$ & $(\%)$ & $(\%)$ & $(\%)$ & $(\mathrm{Kka1} / \mathrm{kg})$ \\
\hline CP 12* & 87.00 & 20.00 & 5.00 & 5.00 & 0.90 & 0.60 & 2965 \\
K. Kopi** & 88.69 & 16.72 & 7.06 & 20.02 & 0.23 & 0.02 & 3063 \\
Dedak*** & 85.59 & 7.91 & 5.91 & 23.37 & 0.22 & 0.95 & 2788 \\
A. Kelapa**** & 88.69 & 11.35 & 23.36 & 14.97 & 0.11 & 0.47 & 3279 \\
T. Ikan*** & 92.16 & 56.91 & 9.34 & 0.90 & 7.04 & 3.67 & 3851 \\
\hline
\end{tabular}

Keterangan: $\mathrm{BK}=$ bahan kering, $\mathrm{PK}=$ protein kasar, $\mathrm{LK}=$ lemak kasar, $\mathrm{SK}=$ serat kasar, $\mathrm{Ca}=\mathrm{Kalsium}$, $\mathrm{P}=$ phosphor, $\mathrm{EM}=$ energi metabolis, $\mathrm{CP} 12$ = pakan komersial, Londok et al. (2018)*, Tulung et al. (2015)**, Londok et al. (2018)***, Novita (2012)****

Tabel 2. Susunan Pakan Perlakuan, Kandungan Zat-zat Makanan dan Energi

\begin{tabular}{lcccc}
\hline \multirow{2}{*}{ Bahan Pakan (\%) } & \multicolumn{3}{c}{ B } & B2 \\
\cline { 2 - 5 } & B0 & B1 & 58 & 34 \\
CP 12 & 100 & 62 & 0 & 0 \\
Kulit Kopi & 0 & 35 & 32 & 0 \\
Dedak & 0 & 0 & 0 & 54 \\
Ampas Kelapa & 0 & 0 & 10 & 12 \\
Tepung Ikan & 0 & 3 & $\mathbf{1 0 0}$ & $\mathbf{1 0 0}$ \\
\hline Total & $\mathbf{1 0 0}$ & $\mathbf{1 0 0}$ & & 88.53 \\
\hline Kandungan zat-zat makanan dan Energi & & 87.06 & 19.76 \\
\hline BK (\%) & 87.00 & 84.98 & 19.82 & 9.44 \\
Protein Kasar (\%) & 20.00 & 19.96 & 5.73 & 1.21 \\
Lemak (\%) & 5.00 & 5.85 & 10.47 & 0.90 \\
Serat Kasar (\%) & 5.00 & 10.13 & 1.30 & 3241 \\
Ca (\%) & 0.90 & 0.85 & 1.02 & \\
P $(\%)$ & 0.60 & 0.49 & 2997 & \\
EM (kkal/kg) & 2965 & 3026 & & \\
\hline
\end{tabular}

Keterangan : Dihitung berdasarkan Tabel 1.

\section{Metode Penelitian}

Metode yang digunakan adalah Rancangan Acak Lengkap (RAL) dengan pola perlakuan Faktorial 2x4 dan 3 ulangan (Kusriningrum., 2010). Perlakuan yang digunakan yaitu: Faktor A: Pembatasan Pakan, dengan taraf faktor A0 (Tanpa Pembatasan), dan A1 (Pembatasan 20\%). Faktor B: Sumber Serat, dengan taraf faktor B0 (Pakan Komersial), B1 (Pakan Komersial dengan Kulit kopi), B2 (Pakan komersial dengan Dedak Padi), dan B3
(Pakan Komersial dengan Ampas Kelapa). Kandungan serat kasar pakan perlakuan sebesar $10 \%$. Terdapat 8 kombinasi perlakuan yaitu: A0B0, A0B1, A0B2, A0B3, A1B0, A1B1, A1B2 dan A1B3.

\section{Prosedur Pemotongan}

Pemotongan dilakukan pada hari ke42, sebanyak 24 ekor ayam (satu ekor untuk masing-masing kombinasi perlakuan dan ulangan) dengan terlebih dahulu dipuasakan 8 jam, setelah itu dilakukan penimbangan bobot hidup akhir kemudian 
dipotong. Pemotongan dilakukan pada bagian leher dengan cara memotong esophagus, pembuluh darah vena jugularis, trakea dan arteri karotidae. Kemudian ayam digantung dengan kepala mengarah ke bawah supaya darah dapat keluar dengan cepat dan sempurna. Setelah itu ayam dicuci bersih. Selanjutnya ayam dicelupkan ke dalam air panas yang bersuhu $71-82{ }^{\circ} \mathrm{C}$ selama \pm 45 detik dilanjutkan dengan pencabutan bulu secara manual. Proses selanjutnya yaitu pemotongan kaki, kepala dan pengeluaran jeroan. Pemotongan komersial serta penimbangan bagianbagian yang terdiri dari dada yang diambil pada daerah scapula sampai pada tulang dada, paha atas diambil pada daerah tulang paha dan dipisahkan dengan persendian pinggul, paha bawah diambil pada daerah persendian paha bawah hingga lutut, sayap diambil pada daerah persendian antara lengan atas dengan scapula dan punggung diambil pada tulang leher hingga buntut.

\section{Peubah}

1. Bobot Hidup (gram)

Bobot Hidup ditimbang sebelum ayam dipotong pada umur 42 hari.

\section{Bobot Karkas (gram)}

Diperoleh dengan menimbang ayam yang telah dipotong dan dikeluarkan kepala, kaki, bulu, dan jeroan

\section{Potongan Komersial}

Diperoleh dengan cara memotong bagian-bagian tubuh, menjadi potongan komersial ( 5 bagian) yaitu, dada, paha atas, paha bawah, sayap dan punggung (Merkley et al., 1980).

- Persentase Bobot Dada

$\%$ bobot dada $=\frac{\text { bobot dada }(\mathrm{g})}{\text { bobot karkas }(\mathrm{g})} \times 100$

- Persentase Bobot Paha Atas $\%$ bobot paha atas $=\frac{\text { bobot paha atas }(\mathrm{g})}{\text { bobot karkas }(\mathrm{g})} \times 100$

- Persentase Bobot Paha bawah $\%$ bobot paha bawah $=\frac{\text { bobot paha bawah }(\mathrm{g})}{\text { bobot karkas }(\mathrm{g})} \times 100$

- Persentase Bobot Sayap

$$
\% \text { bobot sayap }=\frac{\text { bobot sayap }(\mathrm{g})}{\text { bobot karkas }(\mathrm{g})} \times 100
$$

- Persentase Bobot Punggung

$\%$ bobot punggung $=\frac{\text { bobot punggung }(\mathrm{g})}{\text { bobot karkas }(\mathrm{g})} \times 100$

\section{Analisis Data}

Data dianalisis secara statistik menggunakan analisis ragam. Kombinasi perlakuan yang berbeda atau paling sedikit satu kombinasi perlakuan berbeda nyata dilanjutkan dengan uji BNJ.

\section{HASIL DAN PEMBAHASAN}

Hasil penelitian pembatasan pakan dengan pemberian sumber serat yang berbeda terhadap bobot hidup, bobot karkas, dan potongan komersial karkas ayam broiler dapat dilihat pada Tabel 3 . 
Tabel 3. Pengaruh Kombinasi Perlakuan terhadap Bobot Hidup, Bobot Karkas dan Potongan Komersial Karkas Ayam Broiler

\begin{tabular}{|c|c|c|c|c|c|c|}
\hline \multirow{2}{*}{ Peubah } & \multirow{2}{*}{$\begin{array}{c}\text { Pembatasan } \\
\text { Pakan (A) }\end{array}$} & \multicolumn{4}{|c|}{ Sumber Serat (B) } & \multirow{2}{*}{ Rata-rata } \\
\hline & & B0 & B1 & B2 & B3 & \\
\hline \multirow{6}{*}{$\begin{array}{c}\text { Bobot Hidup } \\
\quad \text { (g/ekor) }\end{array}$} & \multirow{2}{*}{ A0 } & 2255,00 & 1846,33 & 2069,82 & 2191,07 & 2090,56 \\
\hline & & $\pm 79,73$ & $\pm 63,31$ & $\pm 105,10$ & $\pm 61,30$ & $\pm 180,02$ \\
\hline & \multirow{2}{*}{ A1 } & 2310,03 & 1693,21 & 2169,10 & 2111,16 & 2070,88 \\
\hline & & $\pm 86,58$ & $\pm 72,34$ & $\pm 124,86$ & $\pm 94,88$ & $\pm 265,27$ \\
\hline & \multirow{2}{*}{ Rata-rata } & 2282,52 & 1769,77 & 2119,46 & 2151,12 & 2080,72 \\
\hline & & $\pm 38,92^{\mathrm{a}}$ & $\pm 108,27^{b}$ & $\pm 70,20^{\mathrm{a}}$ & $\pm 56,50^{\mathrm{a}}$ & $\pm 218,99$ \\
\hline \multirow{6}{*}{$\begin{array}{c}\text { Bobot } \\
\text { Karkas } \\
\text { (g/ekor) }\end{array}$} & \multirow{2}{*}{ A0 } & 1750,00 & 1352,84 & 1572,00 & 1674,81 & 1587,41 \\
\hline & & $\pm 58,51^{\mathrm{a}}$ & $\pm 66,85^{\mathrm{c}}$ & $\pm 17,35^{\mathrm{ab}}$ & $\pm 70,72^{\mathrm{ab}}$ & $\pm 172,56$ \\
\hline & \multirow{2}{*}{ A1 } & 1564,98 & 1337,50 & 1605,23 & 1522,30 & 1507,50 \\
\hline & & $\pm 88,23^{\mathrm{ab}}$ & $\pm 62,79^{c}$ & $\pm 58,83^{\mathrm{ab}}$ & $\pm 88,75^{\mathrm{bc}}$ & $\pm 128,22$ \\
\hline & \multirow{2}{*}{ Rata-rata } & 1657,49 & 1345,17 & 1588,62 & 1598,55 & 1547,46 \\
\hline & & $\pm 130,83$ & $\pm 10,85$ & $\pm 47,07$ & $\pm 107,84$ & $\pm 140,13$ \\
\hline \multirow{6}{*}{$\begin{array}{c}\text { Dada } \\
(\%)\end{array}$} & \multirow{2}{*}{ A0 } & 34,23 & 35,44 & 34,10 & 34,64 & 34,60 \\
\hline & & $\pm 0,55$ & $\pm 0,17$ & $\pm 0,45$ & $\pm 0,97$ & $\pm 0,60$ \\
\hline & \multirow{2}{*}{ A1 } & 34,64 & 35,81 & 34,16 & 34,61 & 34,81 \\
\hline & & $\pm 0,35$ & $\pm 0,71$ & $\pm 0,34$ & $\pm 0,38$ & $\pm 0,71$ \\
\hline & \multirow{2}{*}{ Rata-rata } & 34,44 & 35,63 & 34,13 & 34,63 & 34,70 \\
\hline & & $\pm 0,29$ & $\pm 0,27$ & $\pm 0,04$ & $\pm 0,02$ & $\pm 0,65$ \\
\hline \multirow{6}{*}{$\begin{array}{c}\text { Paha Atas } \\
(\%)\end{array}$} & \multirow{2}{*}{ A0 } & 14,92 & 16,81 & 15,22 & 14,17 & 15,28 \\
\hline & & $\pm 0,14^{\mathrm{ab}}$ & $\pm 0,67^{\mathrm{a}}$ & $\pm 0,85^{\mathrm{ab}}$ & $\pm 0,43^{\mathrm{b}}$ & $\pm 1,11$ \\
\hline & \multirow{2}{*}{ A1 } & 15,25 & 14,19 & 14,58 & 14,59 & 14,65 \\
\hline & & $\pm 0,61^{\mathrm{b}}$ & $\pm 0,12^{\mathrm{b}}$ & $\pm 0,89^{\mathrm{ab}}$ & $\pm 1,30^{\mathrm{b}}$ & $\pm 0,44$ \\
\hline & \multirow{2}{*}{ Rata-rata } & 15,09 & 15,50 & 14,90 & 14,38 & 14,97 \\
\hline & & $\pm 0,23$ & $\pm 1,85$ & $\pm 0,45$ & $\pm 0,30$ & $\pm 0,46$ \\
\hline \multirow{6}{*}{$\begin{array}{c}\text { Paha Bawah } \\
(\%)\end{array}$} & \multirow{2}{*}{ A0 } & 13,23 & 13,06 & 12,68 & 13,70 & 13,17 \\
\hline & & $\pm 0,55$ & $\pm 0,78$ & $\pm 0,06$ & $\pm 0,33$ & $\pm 0,42$ \\
\hline & \multirow{2}{*}{ A1 } & 14,22 & 13,16 & 12,79 & 14,10 & 13,57 \\
\hline & & $\pm 0,42$ & $\pm 0,89$ & $\pm 0,77$ & $\pm 0,36$ & $\pm 0,70$ \\
\hline & \multirow{2}{*}{ Rata-rata } & 13,72 & 13,11 & 12,74 & 13,90 & 13,37 \\
\hline & & $\pm 0,72$ & $\pm 0,07$ & $\pm 0,08$ & $\pm 0,28$ & $\pm 0,54$ \\
\hline & $\Delta 0$ & 9,84 & 10,14 & 9,40 & 10,30 & 9,92 \\
\hline & AV & $\pm 0,96$ & $\pm 0,46$ & $\pm 0,41$ & $\pm 1,13$ & $\pm 0,40$ \\
\hline Sayap & & 10,26 & 10,72 & 10,14 & 10,60 & 10,43 \\
\hline & A1 & $\pm 0,26$ & $\pm 0,79$ & $\pm 0,89$ & $\pm 0,06$ & $\pm 0,27$ \\
\hline & & 10,05 & 10,43 & 9,77 & 10,45 & 10,17 \\
\hline & Rata-rata & $\pm 0,30$ & $\pm 0,41$ & $\pm 0,53$ & $\pm 0,21$ & $\pm 0,33$ \\
\hline & & 19,74 & 19,87 & 18,54 & 22,07 & 20,06 \\
\hline & A0 & $\pm 0,32$ & $\pm 0,90$ & $\pm 0,46$ & $\pm 0,86$ & $\pm 1,47$ \\
\hline Punggung & A1 & 20,75 & 19,80 & 18,33 & 21,21 & 20,02 \\
\hline$(\%)$ & A1 & $\pm 0,52$ & $\pm 1,06$ & $\pm 0,52$ & $\pm 0,59$ & $\pm 1,27$ \\
\hline & & 20,25 & 19,83 & 18,43 & 21,64 & 20,04 \\
\hline & Rata-rata & $\pm 0,71^{\mathrm{ab}}$ & $\pm 0,05^{\mathrm{ab}}$ & $\pm 0,15^{\mathrm{b}}$ & $\pm 0,60^{\mathrm{a}}$ & $\pm 1,32$ \\
\hline
\end{tabular}

Keterangan: Nilai dengan superskrip yang berbeda pada baris yang sama menunjukkan perbedaan yang nyata $(\mathrm{P}<0,05),(\mathrm{P}<0,01)$.

\section{Pengaruh Perlakuan Terhadap Bobot Hidup}

Rataan bobot hidup (Tabel 3) berkisar antara 1693,21-2310,03 g/ekor. Hasil penelitian ini masih lebih tinggi dibandingkan dengan Lesson and Summer (1991) 2223 g/ekor dan Subekti et al. (2012) yaitu 1775-1842 g/ekor. 
Hasil analisis ragam menunjukkan bahwa interaksi perlakuan memberikan pengaruh yang berbeda tidak nyata $(\mathrm{P}>0,05)$. Akan tetapi pada perlakuan sumber serat memberikan pengaruh sangat berbeda sangat nyata $(\mathrm{P}<0,01)$. Hasil uji lanjut $\mathrm{BNJ}$ menunjukkan bahwa B0 berbeda sangat nyata $(\mathrm{P}<0,01)$ dibandingkan dengan $\mathrm{B} 1$ namun sama dengan B3 dan B2 terhadap bobot hidup. Keseimbangan zat-zat makanan terutama protein dan energi sangat penting karena nyata mempengaruhi kecepatan pertumbuhan bobot badan. Berat badan ayam ditentukan oleh jumlah konsumsi pakan dengan kandungan energi dan protein yang seimbang (Allama et al., 2012). Risnajati (2012) menyatakan bahwa bobot hidup yang dicapai pada umur yang sama antara berbagai strain akan berbeda dan hal ini disebabkan selain adanya perbedaan mutu genetik juga disebabkan oleh faktor lingkungan yang mendukung potensi tersebut.

\section{Pengaruh Perlakuan terhadap Bobot Karkas}

\footnotetext{
Rataan bobot karkas (Tabel 3) berkisar antara 1337,50-1750,00 gram/ekor. Hasil penelitian ini masih lebih tinggi dibandingkan dengan hasil penelitian dari Subekti et al. (2012) 1295,25-1404,25 g/ekor dan Kusuma et al. (2014) 915,2 1124,4 g/ekor .
}

Berdasarkan analisis varians menunjukkan bahwa interaksi antara pembatasan pakan dengan sumber serat memberikan pengaruh yang berbeda nyata $(\mathrm{P}<0,05)$. Hasil uji lanjut $\mathrm{BNJ}$ menunjukkan bahwa bobot karkas dari kombinasi perlakuan A0B0 (kontrol) berbeda nyata $(\mathrm{P}<0,05)$ dibandingkan dengan kombinasi perlakuan A1B3, A0B1 dan A1B1 tetapi sama dengan perlakuan A0B3, A1B2, A0B2 dan A1B0. Begitu juga dengan ayam broiler yang mendapatkan kombinasi perlakuan A0B3 berbeda nyata $(\mathrm{P}<0,05)$ dibandingkan dengan kombinasi perlakuan A0B1, A1B1 dan A0B0 tetapi sama dengan kombinasi perlakuan A1B2, A0B2, A1B0 dan A1B3. Dan serupa juga untuk kombinasi perlakuan A1B3 berbeda nyata $(\mathrm{P}<0,05)$ dibandingkan dengan kombinasi perlakuan A1B0, A0B2, A1B2, A0B3 dan A0B0 tetapi sama dengan kombinasi perlakuan A0B1 dan A1B1. Bobot karkas yang dihasilkan dipengaruhi oleh beberapa faktor yaitu umur, jenis kelamin, bobot potong, besar konformasi tubuh, perlemakan, kualitas dan kuantitas ransum serta strain ternak yang dipelihara (Subekti et al., 2012). Rendahnya bobot karkas yang ada pada perlakuan sumber serat kulit kopi, diduga karena kulit kopi mengandung zat antinutrisi seperti tanin dan kafein yang dapat berpengaruh menurunkan daya cerna, konsumsi pakan dan pertumbuhan ayam pedaging. Hal ini 
ditunjang oleh Akmal dan Filawati. (2008) yang menyatakan bahwa terdapat beberapa faktor pembatas penggunaan kulit kopi, diantaranya adalah cukup tingginya kandungan serat kasar serta mengandung zat anti nutrisi seperti tanin dan kafein. Prawitasari et al. (2012), menyatakan bahwa serat kasar dapat membantu gerak peristaltik usus, mencegah penggumpalan ransum dan mempercepat laju digesta. Kadar serat kasar yang terlalu tinggi, pencernaan nutrien akan semakin lama dan nilai energi produktifnya semakin rendah. Serat kasar yang tinggi menyebabkan unggas merasa kenyang, sehingga dapat menurunkan konsumsi karena serat kasar bersifat voluminous.

\section{Pengaruh Perlakuan terhadap Persentase Dada}

Rataan persentase dada (Tabel 3) berkisar antara 34,10-35,81\%. Hasil penelitian ini masih lebih tinggi dibandingkan dengan Massolo et al. (2016) yaitu $25,05-29,51 \%$ dan sejalan dengan penelitian Londok dan Rompis (2018) sebesar 33,84-36,37\%.

Hasil ANOVA menunjukkan bahwa interaksi memberikan pengaruh yang berbeda tidak nyata $(\mathrm{P}>0,05)$. Menurut Lesson dan Summers (1980), dada merupakan komponen utama dari unggas dan secara kuantatif lebih berat bila dibandingkan dengan bagian sayap, punggung dan paha. Massolo et al. (2016) menyatakan bahwa besarnya bobot dada dijadikan ukuran menilai kualitas perdagingan karena sebagian besar otot yang merupakan komponen karkas paling besar terdapat di dada. Londok dan Rompis (2018) komponen karkas yang paling mahal adalah daging dan bagian terbesar daging terdapat di bagian dada, sehingga besarnya dada dijadikan ukuran untuk memperbandingkan kualitas daging pada pedaging.

\section{Pengaruh Perlakuan terhadap Persentase Paha Atas}

Rataan persentase paha atas (Tabel 3) berkisar antara 14,17-16,81 \%. Hasil penelitian ini sejalan dengan Lesson and Summer (1991) yaitu 16,3\%

Hasil analisis ragam bahwa interaksi berbeda sangat nyata $(\mathrm{P}<0,01)$. Hasil uji lanjut BNJ menunjukkan bahwa kombinasi perlakuan A0B1 berbeda sangat nyata $(\mathrm{P}<0,01)$ dibandingkan dengan kombinasi perlakuan A1B1, dan A0B3 sama dengan kombinasi perlakuan A1B0, A0B2, A0B0, A1B3 dan A1B2. Hal yang sama juga untuk kombinasi perlakuan A1B0 berbeda sangat nyata $(\mathrm{P}<0,01)$ dibandingkan dengan kombinasi perlakuan A0B1 tetapi sama dengan kombinasi perlakuan A0B2, A0B0, A1B3, A1B2, A1B1 dan A0B3. Ramdani et al. (2016) menyatakan bahwa 
paha atas merupakan potongan karkas yang mengandung banyak daging kedua terbanyak setelah dada sehingga perkembangannya dipengaruhi oleh kandungan protein. Hal ini terlihat dalam Tabel 2 bahwa komposisi protein dan energi hampir sama.

\section{Pengaruh Perlakuan terhadap Persentase Paha Bawah}

Pada Tabel 3 menunjukkan bahwa rataan persentase paha bawah berkisar antara $12,68-14,22 \%$. Hasil penelitian ini masih lebih tinggi dibandingkan dengan Lesson and Summer (1991) yaitu 13,3\%.

Hasil analisis ragam menunjukkan bahwa interaksi memberikan pengaruh yang berbeda tidak nyata $(\mathrm{P}>0,05)$. Hal ini menunjukkan bahwa semua perlakuan memberikan pengaruh yang sama. Ramdani et al. (2016) menyatakan bahwa persentase daging bagian paha bawah merupakan anggota gerak sehingga komponen daging sedikit dibandingkan daging bagian paha atas.

\section{Pengaruh Perlakuan terhadap Persentase Sayap}

Rataan persentase sayap (Tabel 3) berkisar antara 9,40-10,72\%. Hasil penelitian ini masih lebih tinggi dibandingkan dengan pernyataan dari Lesson and Summer (1991) bahwa rataan persentase sayap ayam broiler umur 6 minggu yaitu 9,74\% dan sejalan dengan penelitian Londok dan Rompis (2018) yaitu berkisar 9,93-10,08\%.

Anova menunjukkan bahwa interaksi memberikan pengaruh yang berbeda tidak nyata $(P>0,05)$. Dengan kata lain semua perlakuan memberikan pengaruh yang sama terhadap persentase sayap. Marzani $e t$ al. (2016) menyatakan bahwa berat karkas akan mempengaruhi persentase karkas dan bagian-bagiannya. Bagian dada dan paha lebih dominan selama pertumbuhan dibandingkan pada bagian sayap. Nita et al . (2015) menyatakan bahwa dengan didasarkan pada ukuran dan struktur bulu sayap, dapat diperkirakan zat-zat makanan berupa protein dan energi akan digunakan dalam jumlah besar untuk pembentukan tulang, daging dan bulu. Hal ini terlihat dalam Tabel 2 bahwa komposisi protein dan energi hampir sama.

\section{Pengaruh Perlakuan terhadap Persentase Pungggung}

Rataan persentase punggung (Tabel 3) berkisar antara 18,33-22,07\%. Hasil penelitian ini sejalan penelitian dari Marfuah (2016) yaitu persentase punggung ayam broiler umur 6 minggu berkisar antara $21,36-22,31 \%$

Analisis ragam menunjukkan bahwa interaksi memberikan pengaruh yang berbeda tidak nyata $(\mathrm{P}>0,05)$. Akan tetapi pada perlakuan sumber serat 
memberikan pengaruh yang sangat nyata $(\mathrm{P}<0,01)$. Hasil uji lanjut BNJ menunjukkan bahwa perlakuan B3 berbeda sangat nyata $(\mathrm{P}<0,01)$ dibandingkan dengan perlakuan B2 namun sama dengan B0 dan B1. Hal yang sama untuk perlakuan B0 berbeda sangat nyata $(\mathrm{P}<0,01)$ dibandingkan dengan perlakuan B3 namun sama dengan perlakuan B1 dan B2. Ramdani et al. (2016) menyatakan bahwa bagian punggung lebih banyak mengandung tulang. Resnawati (2004) menyatakan bahwa punggung ayam pedaging sebagian besar tersusun atas jaringan tulang dan sedikit jaringan otot.

\section{KESIMPULAN}

Pembatasan pakan 20\% dengan ampas kelapa sebagai sumber serat bahan pakan memberikan hasil terbaik terhadap potongan komersial karkas ayam broiler strain Cobb.

\section{UCAPAN TERIMA KASIH}

Ucapan terima kasih disampaikan kepada Pemerintah Republik Indonesia Kementrian Riset Teknologi dan Pendidikan Tinggi, sebagai penyandang dana penelitian dengan nomor kontrak 087/SP2H/LT/DRTM/2018.

\section{DAFTAR PUSTAKA}

Akmal., dan Filawati. 2008. Pemanfaatan kapang Aspergillus niger sebagai inokulan fermentasi kulit kopi dengan media cair dan pengaruhnya terhadap performans ayam broiler. Jurnal Ilmu-Ilmu Peternakan, 11(3):150-158

Allama, H., O. Sofyan, E. Widodo dan H. S. Prayogi. 2012. Pengaruh penggunaan tepung ulat kandang (Alphitobius diaperinus) dalam pakan terhadap penampilan produksi ayam pedaging. Jurnal Ilmu-Ilmu Peternakan 22 (3): 1-8.

Kusriningrum. 2010. Perancangan Percobaan. Airlangga University Press. Surabaya.

Kusuma, R. A., B. Dwiloka, dan L. D. Mahfudz. 2014. Berat karkas, non karkas, dan lemak abdominal pada ayam broiler yang diberi pakan mengandung Salvinia molesta. Animal Agriculture Journal 3 (2): 249 $-257$.

Kusuma, H. A., A. Mukhtar dan R. Dewanti 2016. Pengaruh tingkat pembatasan pemberian pakan (Restricted Feeding) terhadap performan ayam broiler jantan. Jurnal Sains Peternakan 14 (1) : 43 - 51

Lesson S., and J. D. Summer. 1980. Production and Carcass Characteristic of the Broiler Chickens. Poult. Sci. 59:786-798.

Lesson, S. and J. D. Summer. 1991. Comercial Poultry Nutrition. $2^{\text {nd }}$ Ed. University Book. University Guelph, Ontario, Canada.

Londok, J. J. M. R., B. Tulung, Y. H. S. Kowel dan J. E. G. Rompis. 2012. Effect of feed restriction on feed efficiency, carcass qualitu and digestive organs charactheristics of 
broiler. Proceeding the $2^{\text {nd }}$ International Seminar "Feed Safety For Healthy Food". AINI and Faculty of Animal Husbandry, Universitas Padjajaran Jatinangor.

Londok, J. J. M. R. dan J. E. G. Rompis. 2018. Pengaruh pembatasan pakan pada periode starter terhadap potongan komersial 2 strain ayam pedaging. Seminar Nasional VII HITPI. 5-6 November 2018.

Londok, J. J. M. R., R. A. V. Tuturoong dan J. E. G. Rompis. 2018. Pengaruh pembatasan pakan (Feed Restriction) terhadap performa dua strain ayam broiler periode starter. Laporan Akhir (Riset Terapan Unggulan Unsrat).

Mahmood, S., S. Mehmood, F. Ahmad, A. Masood dan R. Kausar. 2007. Effect of feed restriction during starter phase on subsquent growth performance, dressing percentage, relative organ weights and immune response of broiler. Pakistan. J. Vet. 27(3):137141.

Marfuah, N. 2016. Kadar kolesterol daging dan kualitas karkas ayam pedaging dengan penggunaan tepung bawang putih dalam ransum. J. Agrisains 17 (3) : 116-122

Marzani, R., Samadi dan Herawati. 2016. Pengaruh substitusi amtabis yang difermentasi dengan Aspergillus Niger terhadap berat dan persentase karkas kroiler. Jurnal Ilmiah Mahasiswa Pertanian Unsyiah 1 (1): $835-842$

Massolo, R., A. Mujnisa, L. Agustina. 2016. Persentase karkas dan lemak abdominal broiler yang diberi prebiotik inulin umbi bunga dahlia (Dahlia variabillis). Buletin Nutrisi dan Makanan Ternak 12 (2): 50-58

Merkley, S. W., G. W. Weinland, Malone and Chaloupka. 1980. Evaluation of five commercial broiler crosses 2 . eviscerated yield and component Parts. J Poult Sci 59 (8) : 1755 - 1760.

Nita, N. S., E. Dihansih dan Anggraeni. 2015. Pengaruh pemberian kadar protein pakan yang berbeda terhadap bobot komponen karkas dan nonkarkas ayam jantan petelur. Jurnal Peternakan Nusantara. 1 (2) 24422541 .

Novita. 2012. Penggunaan ampas kelapa (Cocos nucifera L.) fermentasi sebagai pakan ayam pedaging terhadap berat badan dan penurunan kadar kolestror darah. http://livestockivestock.blogspot.co m/2012/06/Penggunaan-Ampas-

Kelapa-Cocos-nucifera.html?m=1 [diunduh April 2018].

Prawitasari, R. H., V. D. Y. B. Ismadi dan I. Estiningdriati. 2012. Kecernaan protein kasar dan serat kasar serta laju digesta pada ayam arab yang diberi ransum dengan berbagai level Azolla Microphylla. Animal Agriculture Journal 1 (1) : 417- 483

Ramdani, I. D., D Kardaya dan Anggraeni. 2016. Pengaruh substitusi pakan komersial dengan tepung ampas kelapa terhadap bobot potong dan bobot karkas ayam kampung. Jurnal Peternakan Nusantara. 2 (1) : 24422541

Resnawati, H. 2004. Bobot potong karkas, ayam pedaging yang diberi ransum menggunakan tepung cacing tanah (Lumbricus Rubellus). Seminar Nasional Teknologi Peternakan dan Veteriner. Balai Penelitian Ternak. Bogor.

Risnajati, Dede. 2012. Perbandingan bobot akhir, bobot karkas dan persentase karkas berbagai strain broiler. Jurnal Sains Peternakan. 10 (1) : 11-14 
Subekti, K., H. Abbas dan Zur KA. 2012. Kualitas karkas (berat karkas, persentase karkas, dan lemak abdomen) ayam broiler yang diberi kombinasi CPO (Crude Palm Oil) dan Vitamin C (Ascorbic Acid) dalam ransum sebagai anti stress. Jurnal Peternakan Indonesia.14 (3): 447453.

Tulung, B. 1999. Isu, Kontroversi dan upaya penurunan kolestrerol produk hewani. Pidato Pengukuhan Guru Besar bidang Ilmu Nutrisi dan Makanan Ternak Fakultas Peternakan Universitas Sam Ratulangi, Manado.

Tulung, B., J. J. M. R. Londok dan M. N. Regar. 2015. The effect of length of feeding and level of crude fiber carccas quality and serum cholesterol of broiler chicken. Proceeding the 4nd Internasional Seminar of AINI. Faculty of Animal Husbandry Sam Ratulangi University. Manado. 